\title{
'Moderne eksegese' van die Nuwe Testament - 'n Ondermyning van die Skrifgesag?*
}

\author{
W S VORSTER
}

Dit was die Duitse nuwetestamentikus E Käsemann wat op 'n keer opgemerk het dat daar vir 'n kerk niks gevaarliker is as om met Jesus van Nasaret, wat aan die kruis gesterf het, gekonfronteer te raak nie?' Daarom beskou ek 'n opdrag soos wat in die titel van hierdie artikel gegee is nie alleen interessant nie maar ook hier ter lande teologies relevant. Dit is immers alleen op grond van teologiese besinning dat 'n kerk met Jesus gekonfronteer kan word. My opdrag is om verskeie redes interessant - redes waarop hier nie ingegaan hoef te word nie maar slegs genoem kan word. Reeds uit die formulering wat my opgelê is - blyk dit myns insiens dat hierdie onderwerp nie sonder sy brandnekels sit nie. Die onderwerp is sosiologies, kerkhistories, kerkpolities, fenomenologies, wetenskapteoreties en selfs teologies gesien, om die minste daarvan te sê, interessant! Dit is teologies relevant juis as gevolg van hierdie vir my interessante redes, maar ook en veral omdat ek die hoop koester dat daar op die oomblik 'n proses van teologiese besinning aan die ontstaan is wat hopelik 'n einde sal maak aan die steriele bedryf van tradisionalisme in die naam van die Teologie veral binne die raamwerk van die sogenoemde drie Afrikaanse susterkerke. Niemand sou myns insiens kon ontken nie dat die Teologie meestal hier 'n outoritêre bedryf is wat vanuit 'n ons-het-reeds-by-die-waarheid-gearriveerde-standpunt bedryf word. ${ }^{2}$ In aansluiting hierby sou die eiesoortigheid van die Teologie, die afsonderlikheid van Skrifbeskouing en die aparte hermeneutiek in die Suid-Afrikaanse Teologie in die algemeen ook nie ontken kan word nie. Desondanks en ten spyte van hierdie rug-teendie-muur wyse van teologiesering, kan die Teologie in Suid-Afrika nie sondermeer negatief beoordeel word nie. Per slot van rekening is daar ook beweging en besinning op te merk, besinning wat onder andere hierbo aangemerk is met die benaming 'moderne eksegese'. Daarbenewens sou dit futiel wees om die gesonde band met die geskiedenis van die Teologie sonder meer prys te gee. Is dit nie 'n tipies Suid-Afrikaanse segging om te behou wat goed is uit die verlede en in die toekoms daarop te bou nie?

Ek wil die behandeling van hierdie onderwerp met 'n algemene dog kategoriese stelling begin wat hopelik in die loop van my bespreking daarvan duidelik sal word. Die aanvaarding van 'die' gesag van die Skrif is geen waarborg vir die korrekte eksegese van die Skrif 
nie of selfs ' $n$ voorwaarde vir korrekte eksegese van die Skrif nie. ${ }^{3}$ Deist het volgens my mening gelyk wanneer hy beweer: 'Daar is sekere vertrekpunte binne die raamwerk van die Teologie wat gewoon bely moet word en waarvoor of waarteen geen dwingende argumente - om van bewyse te swyg - aangevoer kan word nie, byvoorbeeld dat God bestaan, dat God Homself geopenbaar het, dat Gods openbaring onder die leiding van die Heilige Gees neerslag gevind het in die Heilige Skrif, dat die Heilige Skrif onfeilbaar, betroubaar, gesagvol, ens. spreek. ${ }^{4}$ Dit beteken egter nie dat die laaste woord oor hierdie sake reeds gesê is nie. Inteendeel alle vooronderstellings is wetenskapsteoreties diskuseerbaar en kontroleerbaar om nie te sê verifieerbaar nie. Stellings soos die 'die Skrif het gesag' is weliswaar nie bewysbaar nie maar is in alle geval diskuseerbaar en moet trouens geekspliseer en daarom gediskuseer word om die houdbaarheid daarvan te toets. Die bedoelings van vooronderstellings, wat terloops nie verkeerd is nie, ${ }^{5}$ is die konstituering van verstaansmodelle maar wat nogtans gekontroleer moet word. Belydenisse is derhalwe tydgebonde, gesitueerd, gekontekstualiseerd en onderworpe aan kontrole! Juis in die lig hiervan is die onderwerp onder bespreking van soveel belang.

In die lig van die beperkings van tyd en ruimte wil ek hierdie onderwerp aan die hand van twee vrae behandel te wete, wat is 'moderne eksegese' van die Nuwe Testament? asook die vraag, wat is Skrifgesag? Die bedoeling is uiteraard nie om 'n uitputtende behandeling van die twee, in sommige aspekte uiteenlopende onderwerpe te bied nie. Ek wil eerder 'n stimulus tot nadenke gee met die oog daarop dat daar 'n gesprek aan die gang kan kom oor albei hierdie sake.

\section{Wat is 'moderne eksegese' van die Nuwe Testament?}

Gedurende die afgelope aantal jare is daar binne die raamwerk van die NTWSA en veral onder die leiding van J P Louw aandag geskenk aan die implikasies van die moderne linguistiek vir die eksegese van die Nuwe Testament. Met behulp van insigte van hierdie dissipline is daar ondersoeke ingestel na verskeie aspekte van die bestudering van die Nuwe Testament en by name van die semantiese aspek van die taal van die Nuwe Testament. Aanvanklik is die aandag toegespits op 'kleiner' sake soos woordsemantiek wat juis in hierdie tyd een van die brandendste probleme van die bestudering van die Nuwe Testament was. Ingeoefen in die metodes van ' $n$ histories-vergelykende benadering van die woorde van die Nuwe Testament, is studente van die Nuwe Testament gekondisioneer om die metodologie van die vorige eeuse argumentasie ten opsigte van woordbeteke- 
nis en woordsemantiek te beoefen. Daarom was dit nie vreemd dat die Cremer-Kittel-Friedrich benadering soveel invloed in die bestudering van die geskrifte van die Nuwe Testament uitgeoefen het nie. Trouens ' $n$ woordteologie van die Kittel-Friedrichtipe was aan die orde van die dag en was trouens Teologie van die Nuwe Testament. Wie homself kon waag op die gebied van die geskiedenis van die woorde van die Nuwe Testament en veral op die gebied van die etimologie, was gereken as 'n outoriteit op die gebied van die Nuwe Testament. Bloot 'geistesgeschichtlich' beskou, is hierdie verskynsel heeltemal verstaanbaar. Trouens, dit was die leuse van die tyd! Wie die geskiedenis van 'n saak kon beskryf, kon ook terselfdertyd die saak self verstaan.

Ondanks verskillende insigte van die moderne linguistiek, wat tot ontsteltenis van meer as een navorser nog tot op die huidige datum nie deurgebreek het in die bestudering van die Klassieke- en ook die Semitiese Tale nie, is daar 'n denkbeweging op tou gesit wat sekere aanvaarbare houdings ten opsigte van die woordsemantiek totaal verander het. Hoewel nie sonder probleme nie, is daar' $n$ totaal nuwe era ingelei in die bestudering van die betekenis(se) waarvoor woorde in die Nuwe Testament gebruik word. Die gevolg hiervan was nie alleen 'n heroriëntering ten opsigte van gebruiksapparate nie maar ook 'n kritiese inoefening in die gebruik van gebruiklike apparate soos die TWNT en BAUER-woordeboeke.

Asof hierdie golf nie sterk genoeg was om alle sekere fondamente te skok nie - per slot van rekening is 'n belangrike 'preekbundel' die TWNT nou die kop ingeslaan - het die heroriëntering nie hierby bly staan nie. Soos in die geval van die moderne linguistiek is die klem in die bestudering van die Nuwe Testament van die woord na die sin verskuif en uiteindelik na die teks of die geheelteks self! Dit is hier waar die term 'moderne eksegese' van die Nuwe Testament ter sprake kom en derhalwe binne hierdie konteks, waar die probleem onder bespreking ter sake is.

Gedurende die afgelope aantal jare is daar steeds meer aandag in die Algemene Taalwetenskap aan die fenomeen 'teks' geskenk. In die Suid-Afrikaanse konteks is daar 'n metode, in aansluiting by die sogenoemde strukturele taalkunde ontwikkel genaamd 'Diskoersanalise' of 'Redevoeringsanalise'. Dit is my opgedra om hierdie metode van teksanalise binne die raamwerk van bogenoemde probleemstelling te bespreek.

Diskoersanalise is ' $n$ poging tot teksanalise wat slegs 'n enkele komponent van 'moderne eksegese' uitmaak. Dit kan, soos later sal blyk, hoegenaamd nie aanspraak maak daarop dat dit'n omvattende eksegetiese metode is nie maar alleen beskou word as 'n poging om deur logiese argumentasie ' $n$ invalspoort in die verstaansproses van 'n gegewe teks te kry. 
Die doel van diskoersanalise is om die argumenteringsrigting, tekskohesie, dit wil sê tekssamehang en teksbinding van 'n gegewe teks of tekseenheid hétsy 'n perikoop of ' $n$ hele geskrif vas te stel en te beskryf met behulp van formele kategorieë.

Een van die belangrikste uitgangspunte van hierdie metode van teksanalise is dat daar met die finale oorgelewerde teks gewerk word wat vooraf tekskrities vasgestel is, met ander woorde met die teks soos wat dit daar in die Grieks staan. Dit is nie ontwerp en kan per definisie nie uitspraak gee oor enige ander aspek van die teks as net die plan van die teks nie. Hoe die relasies in die tekssaamhang, wat die teks saambind, wat die een deel van' $n$ teks met die volgende te make het, dít is die dinge wat met behulp van hierdie metode beskryf kan word. Oor die wording van die teks, oor redaksie en tradisie, oor die verband tussen teks en werklikheid, oor die Nuwe Testament en geskiedenis, oor die ipsissima verba van Jesus, oor geeneen van hierdie sake en nog meer kan 'n mens met behulp van hierdie metode 'n sinnige woord sê nie! Ten opsigte daarvan dat daar van die finale teks uitgegaan word, is hierdie vorm van teksanalise wel 'modern' veral as ' $n$ mens dit teen die agtergrond van die geskiedenis van die eksegese bekyk waar daar veral binne die histories-kritiese benadering tot voor en selfs met die opkoms van die Redaktionsgeschichte meer met die wording van die teks as met die teks self gewerk is. Dit kan ook wat teksopvatting betref nie eenvoudig met die 'teksbeskouing', indien mens so anachronisties mag praat, van die grammaties-historiese eksegese vergelyk word nie. Onderliggend aan hierdie metode is daar' $n$ teksteorie, selfs al sou alle beoefenaars van die metode nie daarvan bewus wees nie, wat saamhang met ' $n$ insig van die literatuurwetenskap waar daar ontdek is dat ' $n$ literêre werk teksimmanent, dit wil sê in homself verstaan kan word sonder inagneming van sy ontstaan, wording en ander historiese gegewens soos outeur en ontvangers.

Hierdie uitgangspunt het niks met 'n positivistiese of fundamentalistiese beskouing van die teks wat uitgelê moet word te doen nie, selfs al word dit dikwels met sodanige beskouinge deur beoefenaars van die metode gepaar. ${ }^{6}$ Die uitgangspunt staan op grond van taalen literêrteoretiese oorwegings op vaste pote. Die gevaar bestaan egter, soos ek in my intreerede opgemerk het, dat dit maklik aanleiding kan gee tot ' $n$ naïewe interpretasie van die geskrifte van die Nuwe Testament veral waar dit gepaar word met 'n positivistiese historisme en ' $n$ ongekontroleerde kanon- en outoriteitsbegrip van die Bybel. En dit is hier waar die 'gesag' van die Skrif myns insiens in gedrang gebring gaan word omdat sy eie-aard misken word.

'n Volgende aspek wat aandag verdien, is die wyse waarop tekssamehang en teksbinding met behulp van hierdie metode beskryf word. Daar is tegnieke ontwikkel om gedagte-eenhede of kola van 
tekste te formaliseer en af te baken. Die teks word derhalwe eerstens in gedagte-eenhede of kola opgebreek. Daarna word die verbande tussen die afsonderlike kola met behulp van onder andere semantiese ekwivalensklasse vasgestel en die kola in kolon-eenhede of 'clusters' ingedeel. Vervolgens word die relasies tussen hierdie kolon-eenhede bepaal en uiteindelik word totale intertekstuele tekssamehange aangedui. Daar word hoofsaaklik lineêr met die teks omgegaan en gekonsentreer op die skarniere ('pivot point') waaromheen die teks uitval. Veral in die diskoersmateriaal van die Nuwe Testament blyk hierdie vorm van struktuuranalise van belang te wees. Dit help om die argumenteringsrigting, tema, samehang en binding van die tekste te orden om met behulp daarvan die argumentasie in die geskrif wat ondersoek word kontrolerend te volg. Daar word met ander woorde gronde gevind waarom 'n uiteindelike interpretasie van 'n teks só en nie anders kan wees nie en dit is op sigself alreeds ' $n$ belangrike saak.

Wat kan daar met behulp van hierdie vorm van teksanalise bereik word? In 'n sekere sin is hierdie vraag reeds beantwoord. Maar ek vind dit nogtans nodig om sonder om te veel te herhaal in te gaan op die vraag as gevolg van ' $n$ hele aantal misverstande wat op die oomblik besig is om die rondte te doen. In die eerste plek bestaan daar tans in Nuwetestamentiese kringe hier en elders in die wêreld ' $n$ babelse verwarring oor wat eksegese is. Dit is deels toe te skryf aan ' $n$ metodekrisis. Dit blyk onder andere uit die groot verskeidenheid publikasies wat gedurende die afgelope tyd die lig gesien het. Drie sake staan in hierdie verband baie duidelik uit. Óf daar word ' $n$ kranige poging aangewend om die tradisionele metodes van eksegese, dit is die histories-kritiese metodes in te oefen ${ }^{7}$ of daar word gepoog om ' $\mathrm{n}$ historiese benadering met ' $\mathrm{n}$ teksimmanente benadering te paar $^{8}$ of daar word totaal gebreek met die historiese benadering en slegs aandag geskenk aan 'n teksimmanente beskouing. Binne hierdie raamwerk moet dit begryp word, maar ook op 'n keer duidelik gesê word dat diskoersanalise nie die laaste woord oor eksegese te sê het nie. Dit is ' $n$ bepaalde metode met behulp waarvan ' $n$ bepaalde vraag beantwoord kan word. In samehang hiermee hoor 'n mens soms, en dan veral by jonger liede van die geïnteresseerdes dat ons nou maar die kommentare op ons rakke kan wegpak of verkoop en die TWNT kan afskryf - ook Bauer moet maar solank verkoop word en die geld belê word vir die dag as die ou uitgediende boeke vervang kan word met die boeke waaraan daar nou geskryf en beplan word. Dit vertoon alleen maar die gevaar van oningeligdheid en ' $n$ gebrek aan formele opleiding in die Taal- en Literatuurkunde. Wie op hoogte is met die stand van sake en wie ' $n$ kritiese oog en oor het, sal met baie groter versigtigheid 'n reeds-gearriveerde-standpunt verkondig. Aan die ander kant sal dit diegene wat onnadenkend die 
goeie ou paaie bewandel sonder enige refleksie oor die tekortkominge van bestaande teorieë noop om te begin aandag skenk aan die reformatoriese leuse van ecclesia reformata semper reformanda est!, wat hoewel oorspronklik anders gebruik, ook in die verband pas.

Wat kan dan met hierdie 'moderne' vorm van eksegese gedoen word? Daar kan ' $n$ invalspoort in die verstaan van die geskrifte van die Nuwe Testament gevind word aan die hand waarvan daar ' $n$ interpretasie van die teks beredeneer kan word. Soos dit tans beoefen word, word die struktuuranalise van die teks ingevul met grammatikale- en semantiese- en selfs 'n vorm van semiotiese analise wat baie nou aansluit by die Nida-model van dinamies-ekwivalente Bybelvertaling. Dit is met ander woorde' $n$ gekontroleerde poging om na te sê wat die teks in Grieks sê en as sodanig beskou 'n konsekwente poging om linguistiese insigte wat met die moderne taalwetenskap saamhang, in die eksegese van die Nuwe Testament in te voer. Een ding moet egter baie duidelik onthou word naamlik dat ' $n$ mens met 'n bepaalde metode 'n bepaalde vraag wil beantwoord. En die vraag wat in dié verband geld, is alleen dit: Hoe word daar gekontroleerd in byvoorbeeld op Afrikaans gesê wat die geskrifte van die Nuwe Testament op Grieks sê. Hoe hang die dele van 'n geskrif in die Nuwe Testament met die geheel van die geskrif saam? Dit is al wat met hierdie metode in sy huidige teoriesamehang bereik kan word. Met hierdie metode kan daar geen vraag oor die ontstaan, wording of watter ander aspek ookal van die moontlike legitieme vrae wat aan die geskrifte van die Nuwe Testament gevra kan word, beantwoord word nie. Indien daar 'n poging aangewend word om meer as dit met die metode te bereik, word die metode illegitiem oorvra! Vandaar my opmerking hierbo dat diskoersanalise volg na interpretasie waarin sake soos tekssoorte, teks en kommunikasie en dergelike aangeleenthede ter sprake kom. My persoonlike mening is dat daar 'n onderskeid gemaak moet word tussen ondersoek na die wording van 'n teks en die uitleg van die teks self. Eersgenoemde hoort tot die voorarbeid vir die eksegese en laasgenoemde wat diskoersanalise kan insluit maar veel meer is as diskoersanalise tot die interpretasie.

Diskoersanalise is 'n stap van 'moderne eksegese' maar alles behalwe die laaste stap. Hoe raak hierdie 'moderne' eksegese nou die vraag van Skrifgesag? Om hierdie vraag te beantwoord, sal ek kortliks ingaan op die vraag van wat Skrifgesag is.

\section{Wat is Skrifgesag?}

Die blote feit dat hierdie vraag nog vandag en veral vandag gevra word en verskillend beantwoord word, is aanduiding daarvan dat daar nie konsensus oor die aangeleentheid bestaan nie. Titels soos die volgende is volop in teologiese literatuur buite Suid-Afrika te 
vinde: 'Die Bybel in gedrang', 'Woord van God in 'n krisis', 'Stryd rondom die Bybel', 'Bybelkritiek en die outoriteit van die Bybel', 'Die Bybel in die moderne wêreld' en talle andere. In al dié geskrifte word daar teologies gewoel en geworstel rondom die verstaan van die gesag van die Skrif. Kyk 'n mens na die Suid-Afrikaanse teologiese toneel is dit opmerklik met watter selfversekerdheid daar oor hierdie teologiese onderwerp geskryf word - nie dat die onderwerp hier baie aandag geniet nie. Die term word wel dikwels los en vas gebruik en onproblematies toegepas veral wanneer daar teologies ongereflekteerd en ongenuanseerd gepraat word. By gebrek aan teologiese kompetensie word daar 'n beroep op die gesag van die Skrif gedoen of as 'n argument nie meer teologies deurgevoer kan word nie word Skrifgesag ingeroep om die geeste te besweer en die argument te beklink. Trouens, ons word nou al gewaarsku teen 'die groot aanslag teen die Skrifgesag soos bely in ons Gereformeerde Belydenisskrifte'. ${ }^{9}$

'n Mens kan die saak op verskillende maniere hanteer maar een ding staan vas en dit het ons reeds ter inleiding gestel, sake soos Skrifgesag wat vooronderstellings is, is daar om geëkspliseer te word. Wie die term op die lippe neem, moet bereid wees om die saak waarom dit vir hom gaan, te verduidelik en redes aan te voer waarom hy die saak sien soos wat hy dit sien. Daar is dus niks verkeerd daarmee om die gesag van die Skrif te bely nie solank as wat ons dit maar kan verduidelik en bereid is om ons verduideliking vir diskussie oop te stel.

Een van die uitgangspunte wat ek hier as aanvaarbaar wil stel, is dat die Nuwe Testament as boek van die kerk, iets vir die kerk te sê het. Hoewel die geskrifte van die Nuwe Testament nie in die eerste plek vir'n breër publiek as die eerste lesers geskryf is nie, en sonder twyfel nie met die oog op ons mense wat in die twintigste eeu leef ontwerp is nie, kan ons dit as vertrekpunt aanvaar, hoewel ook die opvatting dat hierdie geskrifte vir die mens en by name vir die Christen van vandag iets te sê het, oopstaan vir diskussie. Dit maak nogal ' $n$ verskil of ' $n$ mens hierdie standpunt as uitgangspunt neem of nie. ${ }^{10}$ Daar word immers hierteenoor soms geredeneer dat die Bybel 'n boek soos alle ander boeke is wat geen 'hoër' status as enige ander boek uit die antieke geniet nie. Dit egter daar gelaat. My vertrekpunt lê elders.

Die term Skrifgesag word in die drie Afrikaanse publikasies wat ek hier wil noem, deurgaans as 'n objektiewe grootheid poneer. Die wyse waarop Duvenhage die term hanteer, blyk uit sy bespreking van die sogenaamde 'radikale Bybelkritiek'. 'Die Bybel is nie identies met besondere openbaring nie hoewel in die Bybel openbaring gevind word. In die kritiese ondersoek word alle natuurwetenskaplike en historiese segmente van die Bybel, en selfs sommige teolo- 
giese en etiese, beskou as behorende tot die produk van bloot menslike arbeid. Daarmee word die goddelike outoriteit van die Skrif nie alleen bevraagteken nie maar totaal op losse skroewe gestel. Die Skrif word onderwerp aan die subjektiewe oordeel van die kritiese navorser en in sy onderwerping van die Skrif aan sy eie historiese insigte kruip die reële gevare om die hoek dat die geloof afhanklik gemaak word van die wetenskap en die heilige Skrif in sy outoritatiewe karakter aangetas word. ${ }^{11}$ Afgesien daarvan dat dit ' $n$ foutiewe en valse weergawe van die sogenaamde 'Bybelkritiek' is, blyk dit duidelik uit die 'probleme' wat hier genoem word wat daar van die Bybel gemaak word wanneer daar gepraat word van 'natuurwetenskaplike en historiese segmente van die Bybel'. Wat hier as kritiek teen die Bybelkritiek uitgespreek word aan die begin van sy rede, spel Duvenhage veertig bladsye later uit en verraai hy sy bron van waaruit hy sy 'gesagsbeskouing' inlegkundig in die tradisie inweef wanneer hy sê: 'Die Heilige Skrif is naamlik totalitêr in sy gesagsaanspraak: dit gaan oor alles en almal. ... Aan dié totalitêre gesagsaanspraak van die Woord kon die Christelike wetenskap en die Christelike beoefenaar van die wetenskap hulle dus nie onttrek nie. Vanuit 'n Christelike wetenskapsbeskouing en wetenskapsbeoefening stel die mens hom onvoorwaardelik onder die gesag van die Heilige Skrif en weet hy hom volkome afhanklik van die genade van God in Christus. ${ }^{12}$ Uitgangspunt van hierdie beskouing is die Christelike wetenskap van Dooyeweerd en 'n verdediging van die begrip 'Skrifgesag' soos hanteer deur die gereformeerde tradisie teenoor andersdenkendes. Dit blyk onder andere uit die wyse waarop daar omgegaan word met die eie-aard van die Skrif soos byvoorbeeld in die bespreking van die sogenaamde onderskeiding tussen normatiewe en historiese gesag van die Skrif (p 22-23), die skrywer se opvatting oor die Bybel en geskiedenis ( $p$ 4, 24 en ander), die betroubaarheid van die Skrif (p 21 - wat beteken dit dat die Gees met onderlinge verskille ' $n$ 'besondere bedoeling' gehad het?) en talle ander sake waarop hier nie ingegaan hoef te word nie. In kort, dit kom daarop neer dat Skrifgesag vasstaan en bevestig word met 'n beroep op leerstukke uit die Dogmatiek wat self ook probleme het. Daar word tevergeefs in die stuk gesoek na ' $n$ indringende bespreking van egte probleme soos byvoorbeeld 'Die Bybel en geskiedenis', teensprake in die Bybel, die feit dat die Bybel oor 'n tydperk van 1500+ jare ontstaan het of wat gesag beteken. Die Skrifgesag staan vas.

Heyns, welbewus van ander menings en standpunte skryf, 'Afgesien van die huidige gesagskrisis wat ons op talle terreine belewe, kan ons kategories beweer dat die Skrif inderdaad gesag het'. ${ }^{13}$ Volgens hom het die Bybel nie gesag omdat dit 1 . 'n boek van mense is nie of 2. omdat dit ' $n$ boek van die kerk is nie of 3. omdat dit ' $n$ boek van historiese betekenis is en die oudste dokument is waarin die 
apostoliese boodskap vervat is nie maar 'Die Bybel het gesag, omdat, en alléén omdat dit die boek is van Gods spreke, en dáárom het die Bybel ook as boek van mense, as boek van en vir die menslike eksistensie, as boek van die kerk en as boek uit die geskiedenis, ' $n$ boodskap en dus gesag. ${ }^{14}$ Hy beweer verder dat die gesag van die Skrif direk met 'die openbaring' en 'die teopneustie' saamhang en dat dit geestelik van aard is. In sy bespreking van wat Skrifgesag eintlik is, maak hy 'n onderskeid tussen skopiese en periferiese gesag ${ }^{15}$ en in die lig hiervan kan hy tot onmoontlike moontlikhede kom soos byvoorbeeld, 'Eerder as om te beweer dat bepaalde gedeeltes in die Skrif vir ons vandag nie meer gesag het nie, moet ons liewer sê: alles in die Skrif het wél gesag, maar nie op dieselfde wyse nie ${ }^{16}$ of elders 'Op die skopiese gesag wat die mens direk aanspreek, is die mens direk en onmiddellik gehoorsaam; op die periferiese gesag wat hom indirek aanspreek, is hy indirek en onmiddellik gehoorsaam. Wie op die liefdesverklaring van God in Johannes 3:16 met wederliefde antwoord, het daarmee implisiet en indirek ook gehoorsaamheid betoon aan alle periferiese gesagsuitsprake in die Ou en die Nuwe Testament en dus ook aan Levitikus 7:23 - "ook al eet hy nog steeds skaapvet saam met sy braaivleis!"'17 Met die beste wil ter wêreld, kan ek hierdie onderskeidinge nie begryp nie, laat staan om dit te hanteer. ${ }^{18}$

In aansluiting by J Bright in sy boek 'The Authority of the Old Testament' soek P A Verhoef die Skrifgesag en by name die gesag van die Ou Testament in die 'Bybelse Teologie' of soos hy dit wil, in die 'teologiese struktuur' van die Ou en die Nuwe Testament. ${ }^{19}$ Aangesien die sleutel vir die gesag van die Bybel in sy Teologie gevind word, word die probleem wat Heyns hierbo met skopies- en periferiese gesag probeer oplos het, opgevang terwyl die Bybel nou in al sy dele gesag het want die gesag lê in die Teologie van die Bybel wat in al sy tekste tot uitdrukking kom. ${ }^{20}$ Dit is egter interessant dat Verhoef nie sy artikel hier afsluit nie maar melding maak van die historisiteitsproblematiek in die Ou Testament. 'Ons is bewus daarvan dat daar allerlei historiese en godsdienshistoriese gegewens is wat skynbaar nie 'klop' nie'. ${ }^{21}$ Maar hier word die skrywer kopsku want die 'betroubaarheid' van die Skrif en daarmee die gesag van die Skrif in sy hantering van die sake - kom hier in gedrang. Dit noop hom om te vra, 'Beoefen ons nog die Gereformeerde reserwe teenoor die resultate van die historiese kritiek, wanneer ons saam met Hartvelt verklaar dat Jerigo nie in werklikheid geval het soos dit in die boek Josua beskryf is nie?' ${ }^{22}$ en pleit hy vir 'n gesonde instelling teenoor die Bybel.

Ook die uitvlug in die soeke na die gesag van die Skrif in sy Teologie kom nie verby die 'tergende' eie-aard van die Skrif nie. Dit is nou eenmaal 'n ou boek in 'n nuwe wếreld wat God deur mense laat skryf 
het en daarom bestaan daar vandag soveel ope vrae oor die begrip 'Skrifgesag'.

Dit blyk uit aldrie hierdie voorafgaande modelle dat die term 'Skrifgesag' ' $n$ outoritêre aard het en verder dat die modelle nie sonder hulle probleme is nie.

Dit was $E$ Jüngel wat 'n onderskeiding tussen outoritêr ('authoritarian') en gesaghebbend ('authoritative') in die diskussie rondom die status van die Bybel probeer invoer het. ${ }^{23}$ Hierdie onderskeid waarvan die betekenis en implikasies voor die handliggend is, het veel voor te sê. In die eerste plek hou dit rekening met kontemporêre probleme rondom die gebruik van die woord 'gesag' en word daar duidelik geïmpliseer wat daar bedoel word met Skrifgesag ó dit nou na die een of die ander kant toe uitgewys word. Dit gaan derhalwe nie om ' $n$ woord alleen nie maar om duidelik te sê wat daarmee bedoel word.

Hierdie saak hang baie nou saam met dit wat ek aan die begin van my bespreking oor die gesag van die Skrif genoem het as uitgangspunt. Die vraag wat ons vandag moet beantwoord oor die gesag van die Skrif, is wat het die Skrif vandag vir die kerk te sê? Ons uitgangspunt was juis dat die Skrif iets te sê het! Ons beskou derhalwe die Skrif as gesaghebbend oor aangeleenthede wat die kerk vandag raak, nl. oor die saak van Jesus! Uiteraard is daar nou allerlei vrae wat opduik. In 'n ondersoek van die Wêreldraad van Kerke oor die gesag van die Skrif gedurende 1968 het die kommissie wat met die saak gewerk het die volgende ses probleemgebiede afgebaken:

1. Die vraag na voorkeure in die Bybel en die verband daarmee met die gemeenskap waaruit dit voortgekom het.

2. Die vraag na verskeidenheid in die Bybel.

3. Die vraag wat ontstaan as gevolg van 'n veranderde wêreldbeeld sedert Bybelse tye en die tydspan tussen nou en destyds.

4. Die vraag na verbande tussen verlede en toekoms met verwysing na Skrifgesag.

5. Die vraag na die verband tussen Bybelse en ander vorme van gesag.

6. Vrae oor die gebruik, funksie en toepassing van Bybelse materiaal. $^{24}$

'n Mens sou hierdie vrae uiteraard kon uitbrei. Genoeg om te sê dat hierdie soort vrae die ondersoeker laat begryp hoe belangrik dit is om erns te maak met die eie-aard van die Bybel en in die lig daarvan te begin soek na'n beskrywing van die gesag van die Skrif. Dit is uit die selfgetuienis van die Skrif duidelik dat dit sowel 'n goddelike as 'n menslike kant het. Wat die Nuwe Testament betref, het ons tekste oor God se Seun wat ons myns insiens kan beskou as die kerugma van die vroeë kerk waaraan ons onsself kan oriënteer. Hierdie tekste 
wat uiteenlopend van aard is, het ' $n$ ontstaans- en 'n wordingsgeskiedenis agter die rug en is deur mense uit ' $n$ baie ver verlede geskryf. Die boeke is vir ons deur die toedoen van God daargestel en dit is ons taak om hulle aan die praat te kry en na aanleiding van die tekste oor God teologiese uitsprake te maak wat ons met Jesus Christus sal konfronteer. In hierdie sin aanvaar ons die uitdaging van die enigste vir ons, genoegsame gesaghebbende bron oor die saak van Jesus.

Is diskoersanalise 'n ondermyning van die Skrifgesag? Ek dink dit behoort duidelik te wees dat hierdie vraag 'n oorvraging van die metode sowel as die term Skrifgesag is. As metode kan dit nie die Skrifgesag ondermyn nie. Wie hierdie metode gaan inklee met nie-virdie-metode-relevante opmerkings die kan wel die gesaghebbendheid van die Skrif ondermyn!

\section{VOETNOTAS}

* Voordrag gelewer voor die Pretoriase broederkring van die Nederduitsch Hervormde Kerk van Afrika op 10 Februarie 1978.

1. E Käsemann, Vom theologischen Recht itistorisch-kritischer Exegese, ZThK 64(1967) 259.

2. Die SATV-program 'Op die weegskaal' van onder andere 78-02-05 waarin verteenwoordigers van die NG Kerk verslag gedoen het oor die samespreking met afgevaardigdes van die Gereformeerde Kerk in Nederland bevestig hier die tipering. Die houding van di D P M Beukes en J Potgieter oor onder andere leeraangeleenthede rondom Prof. Kuitert en Dr. Wiersinga getuig van 'n probleemlose klaaruitgemaakte standpunt. Daar moet nou opgetree word - Kuitert moet in sy arbeid gestuit word!

3. Sien Barr, J The Bible in the Modern World. London: SCM Press 1973, 31 n.14.

4. Deist, F E Historiese Heuristiek, Teologiese Hermeneutiek en Skrifgesag, Universiteit van Port Elizabeth Navorsingspublikasie c11, 1976, 1.

5. Sien Stanton, G N Presuppositions in New Testament Criticism, in Marshall, I $\mathrm{H}$ (ed.) New Testament Interpretation. Essays on Principles and Methods. Exeter: The Paternoster Press 1977, 60vv.

6. Sien byvoorbeeld Coetzee, J C'n Pleidooi vir vernuwing in die besondere kanoniek - toegelig aan die hand van die evangelie van Johannes, Wetenskaplike Bydraes van die PU vir CHO. Reeks H: Inougurele Redes Nr. 29, Potchefstroomse Universiteit vir $\mathrm{CHO}$. Vergelyk hierteenoor Vorster, $\mathrm{W} S$ 'n Ou Boek in 'n nuwe wêreld - gedagtes rondom die interpretasie van die Nuwe Testament. Intreerede. Miscellanea 10, Unisa 1977.

7. Sien byvoorbeeld Conzelmann, $\mathrm{H}$ en Lindemann, A Arbeitsbuch zum Neuen Testament, Tübingen: J C B Mohr 1975.

8. Sien Berger, K Exegese des Neuen Testaments, Heidelberg: Quelle \& Meyer 1977.

9. Coetzee, J C Stryd op Drumpel, Die Kerkblad, 77-07-13.

10. Sien Barr, a w, 35vv.

11. Duvenhage, S C W Die Gesag van die Heilige Skrif. Inougurele Rede, Potchefstroom: Instituut vir Bevordering van Calvinisme 1967, 4.

12. Ibid., 42.

13. Heyns, J H Brug tussen God en Mens. Pretoria: NG Kerkboekhandel 1973, 124.

14. Ibid., 125.

15. Ibid., 131.

16. Ibid., 132 .

17. Ibid. 
18. Vergelyk verder byvoorbeeld Heyns se bespreking oor vroue se hare. Ibid., 135.

19. Verhoef, $P$ A Die Gesag van die Ou Testament in die Christelike Kerk, NGTT 10(3, 1969) 135-153.

20. Ibid., 142.

21. Ibid., 144.

22. Ibid., 151.

23. Sien Barr, J The authority of the Bible, The Ecumenical Review, 21(1969) 150.

24. Ibid., p 145. 